Uncertain Citizenship 



\section{Uncertain Citizenship}

Everyday Practices of Bolivian

Migrants in Chile

Megan Ryburn

\section{ए}

UNIVERSITY OF CALIFORNIA PRESS 
University of California Press, one of the most distinguished university presses in the United States, enriches lives around the world by advancing scholarship in the humanities, social sciences, and natural sciences. Its activities are supported by the UC Press Foundation and by philanthropic contributions from individuals and institutions. For more information, visit www.ucpress.edu.

University of California Press

Oakland, California

(C) 2018 Megan Ryburn

Library of Congress Cataloging-in-Publication Data

Names: Ryburn, Megan, author.

Title: Uncertain citizenship : everyday practices of Bolivian migrants in Chile / Megan Ryburn.

Description: Oakland, California : University of California Press, [2018] | Includes bibliographical references and index. |

Identifiers: LCCN 2018014113 (print) | LCCN 2018017092 (ebook) | ISBN 9780520970793 (ebook) | ISBN 9780520298767 (cloth : alk. paper) | ISBN 9780520298774 (pbk. : alk. paper)

Subjects: LCSH: Bolivia-Emigration and immigration. | Immigrants-Bolivia-Social conditions. | Foreign workers, Bolivian-Chile—Social conditions. | Bolivians-Chile—Social conditions.

Classification: LCC HD8268.5.B65 (ebook) | LCC HD8268.5.B65 R93 2018 (print) | DDC 305.868/84083-dc23

LC record available at https://lccn.loc.gov/2018014113

$\begin{array}{llllllllll}27 & 26 & 25 & 24 & 23 & 22 & 21 & 20 & 19 & 18\end{array}$

$\begin{array}{llllllllll}10 & 9 & 8 & 7 & 6 & 5 & 4 & 3 & 2 & 1\end{array}$ 
For Liz Ryburn, and in memory of Murray Ryburn 
